\title{
Pertanggungjawaban Administratif Juru Parkir di Tepi Jalan Umum Dalam Pemungutan Retribusi
}

\author{
Hasfar Fuadi, Ilyas Ismail dan M. Saleh \\ fuadihasfar@gmail.com \\ Universitas Syiah Kuala
}

\begin{abstract}
Keywords: $\quad$ Abstract
Accountability; This paper uses a juridical empirical research method. Juridical research is using a Retribution; Statutory approach, namely Qanun/Perda (dass sollen), while empirical research uses a Parking. $\quad$ field approach (dass sein) by conducting direct interviews with parking attendants and parking retribution users. This study aims to understand and determine the responsibility of parking attendants on the edge of public roads in collecting retribution and applying sanctions to irresponsible parking attendants on the edge of public roads. The results of the study show that the parking attendant is required to use the official clothes/vest provided by the Banda Aceh City Transportation Service, the parking attendant at the time of collecting the parking fee is required to submit a coupon to the user of the retribution service as proof of the parking levy collection and the parking attendant is obliged to submit the levy result to the Banda City Government Aceh through the Quotation Officer assigned in accordance with the provisions that have been set, but if the parking attendant does not carry out his obligations, he will be given a sanction in the form of cancellation of the Management Agreement for the Collection of Parking Retribution. By submitting the coupon as proof of payment of the parking fee, the user of the levy service will count the number of vehicles entering and leaving.
\end{abstract}

Kata Kunci: $\quad$ Abstrak

Pertanggungjawa- Tulisan ini menggunakan metode penelitian yang bersifat yuridis empiris. ban; Retribusi; Penelitian yuridis adalah menggunakan pendekatan peraturan perundangParkir. undangan yaitu Qanun/Perda (dass sollen), sedangkan penelitian empiris menggunakan pendekatan lapangan (dass sein) dengan melakukan wawancara langsung terhadap Juru Parkir dan pengguna retribusi parkir. Penelitian ini bertujuan untuk memahami dan mengetahui pertanggungjawaban Juru Parkir di tepi jalan umum dalam pemungutan retribusi dan penerapan sanksi terhadap Juru Parkir di tepi jalan umum yang tidak bertanggung jawab. Hasil penelitian bahwa Juru Parkir wajib menggunakan pakaian/rompi resmi yang diberikan oleh Dinas Perhubungan Kota Banda Aceh, Juru Parkir pada saat memungut retribusi parkir wajib menyerahkan kupon kepada pengguna jasa retribusi sebagai bukti pungutan retribusi parkir dan Juru Parkir wajib menyerahkan hasil retribusi kepada Pemerintah Kota Banda Aceh melalui Juru Kutip yang ditugaskan sesuai dengan ketentuan yang telah ditetapkan, namum apabila Juru Parkir tidak melaksanakan kewajibannya maka akan diberikan sanksi berupa pembatalan Surat Perjanjian Tata Kelola Pemungutan Retribusi Parkir. Dengan diserahkannya kupon sebagai tanda bukti pembayaran retribusi parkir maka pengguna jasa retribusi akan terhitung jumlah kendaraan yang masuk dan keluar.

Copyright (c) 2021 Hasfar Fuadi, Ilyas Ismail dan M. Saleh. (cc)(i) Published in Media Iuris. Published by Universitas Airlangga, Magister Ilmu Hukum. 
Hasfar Fuadi, dkk: Pertanggungjawaban Administratif Juru...

\section{Pendahuluan}

Qanun Kota Banda Aceh Nomor 4 Tahun 2012 tentang Retribusi Pelayanan Parkir Di Tepi Jalan Umum dalam Pasal 10 ayat (3) disebutkan bahwa "retribusi dipungut dari juru parkir oleh pengutip dengan menggunakan kupon sebagai tanda bukti pembayaran retribusi parkir". Bahwa tujuan dibentuk qanun ini adalah seyogyanya untuk peningkatan pelayanan parkir di tepi jalan umum pada masyarakat secara optimal oleh Pemerintah Kota Banda Aceh perlu didukung oleh dana yang cukup dari sumber Pendapatan Asli Daerah (PAD).

Peraturan Walikota Banda Aceh Nomor 6 Tahun 2013 tentang Penyelenggaraan Perparkiran dalam Pasal 5 ayat (1) dan ayat (4), Pasal 12 ayat (2) dan Pasal 6 huruf a-g. Dalam Pasal 5 ayat (1) menyebutkan bahwa "dalam menyelenggaran parkir di tepi jalan umum Walikota atau Pejabat yang ditunjuk, menugaskan Juru Parkir dengan Surat Tugas". Dalam penjelasannya mengenai Pasal 5 ayat (1) yang bahwa Walikota Banda Aceh menunjuk seorang Juru Parkir melalui Dinas Perhubungan Kota Banda Aceh, yang kemudian Kepala Dinas Perhubungan Kota Banda Aceh memerintahkan Kepada Bidang Perparkiran Dinas Perhubungan Kota Banda Aceh untuk memproses permohonan yang diajukan oleh calon Juru Parkir untuk dijadikan sebagai Juru Parkir resmi di tepi jalan umum Kota Banda Aceh.

Kemudian pada ayat (4) disebutkan bahwa "Surat tugas bagi juru parkir berlaku selama 6 (enam) bulan dan dapat diperpanjang" berkenaan dengan Surat Tugas juru parkir penjelasannnya adalah surat tugas berupa Surat Perjanjian Tata Kelola Pemungutan Retribusi Parkir yang dikeluarkan oleh Dinas Perhubungan Kota Banda Aceh.

Bahwa berkaitan dengan lokasi parkir yang pada dasarnya calon Juru Parkir di tepi jalan umum mengajukan permohonan kepada Dinas Perhubungan Kota Banda Aceh untuk dilakukan survei terhadap lokasi yang diajukannya, kemudian Dinas Perhubungan Kota Banda Aceh memerintahkan petugas untuk melakukan survei ke lokasi yang diajukan oleh calon Juru Parkir di tepi jalan umum terhadap lokasi tersebut. 
Selanjutnya pada Pasal 6 menyebutkan bahwa "Juru Parkir wajib untuk: menggunakan pakaian seragam, tanda pengenal serta perlengkapan lainnya yang ditetapkan oleh Walikota atau Pejabat yang ditunjuk, menjaga kebersihan, keindahan dan kenyamanan lingkungan parkir, menyerahkan karcis parkir sebagai tanda bukti untuk setiap kali parkir pada saat memasuki lokasi parkir dan memungut retribusi sesuai dengan qanun, menggunakan karcis parkir resmi yang diterbitkan Pemerintah Kota yang disediakan untuk satu kali parkir dan tidak boleh digunakan lebih dari satu kali, menyetorkan hasil retribusi sesuai ketentuan yang berlaku, menata dengan tertib kendaraan yang diparkir, baik pada waktu datang maupun pergi, dan tidak lebih dari satu baris dan melakukan pembinaan terhadap pembantu juru parkir".

Selanjutnya bahwa selain diatur dalam perundang-undangan terkait dengan perparkiran, “Dinas Perhubungan Kota Banda Aceh perjanjian tertulis antara Dinas Perhungan Kota Banda Aceh dengan calon Juru Parkir sebagaimana tertuang dalam perjanjian Nomor 974/ /SPRP/2018 tentang Surat Perjanjian Tata Kelola Pemungutan Retribusi Parkir".

Bahwa untuk besarannya tarif retribusi parkir sebagaimana dalam Qanun Kota Banda Aceh Nomor 4 Tahun 2012 tentang Retribusi Pelayanan Parkir di Tepi Jalan Umum pada Pasal 8 ayat (1) dan ayat (2). Pada Pasal 8 ayat (1) disebutkan bahwa "struktur tarif retribusi digolongkan berdasarkan Jenis Kendaraan". Sedangkan pada ayat (2) disebutkan bahwa "struktur dan besarnya tarif sebagaimana dimaksud pada ayat (1) ditetapkan sebagai berikut:

Tabel 1.

\begin{tabular}{lll}
\hline No. & \multicolumn{1}{c}{ Jenis Kendaraan } & \multicolumn{1}{c}{ Tarif } \\
\hline 1. & Roda 2 (dua) dan sejenisnya & Rp. 1.000,- / sekali parkir \\
2. & Roda 3 (tiga) dan sejenisnya & Rp. 1.000,- / sekali parkir \\
3. & Roda 4 (empat) dan sejenisnya & Rp. 2.000,- / sekali parkir \\
4. & Roda 6 (enam) dan sejenisnya & Rp. 6.000,- / sekali parkir \\
\hline
\end{tabular}

Sumber. Qanun Kota Banda Aceh Nomor 4 Tahun 2012

Namun sebagian Juru Parkir di tepi jalan umum masih belum melaksanakan kewajiban-kewajiban sebagai Juru Parkir sebagaimana yang telah dijelaskan 
Hasfar Fuadi, dkk: Pertanggungjawaban Administratif Juru...

dalam "Pasal 6 Qanun Kota Banda Aceh Nomor 4 Tahun 2012 tentang Retribusi Pelayanan Parkir di Tepi Jalan Umum. Jika pada salah satu poin pada Pasal 6 tidak dipenuhi oleh Juru Parkir di tepi jalan umum Juru Parkir dapat diberikan sanksi sebagaimana terdapat dalam Surat Perjanjian Tata Kelola Pemungutan Retribusi Parkir, kemudian Kepala Dinas Perhubungan Kota Banda Aceh melalui Kepala Bidang Perparkiran dapat membatalkan surat perjanjian tersebut".

Peranan pemerintah daerah dalam menggali dan mengembangkan berbagai potensi daerah sebagai sumber penerimaan daerah akan sangat menentukan keberhasilan pelaksanaan tugas pemerintah, pembangunan dan pelayanan masyarakat di daerah. Dalam mewujudkan peran pemerintah daerah tersebut, satu hal yang harus dimiliki oleh daerah adalah kemampuan dalam penyediaan pembiayaan pembangunan yang bertumpu pada sumber pendapatan daerah yang lebih besar. ${ }^{1}$

Walaupun pemerintah Kota Banda Aceh telah mengatur tentang aturan mengenai retribusi parkir di tepi jalan umum serta tentang penyelenggaraan perparkiran dari aturan yang tertinggi sampai dengan aturan yang terendah masih ada juru parkir resmi di Kota Banda Aceh yang belum memenuhi hak dalam hal penyerahan kupon retribusi parkir dan kewajibannya melaksanakan sebagaimana dalam Pasal 6 Qanun Kota Banda Aceh Nomor 4 Tahun 2012 tentang Retribusi Pelayanan Parkir Di Tepi Jalan Umum serta perjanjian yang telah disepakati didalam Surat Perjanjian Tata Kelola Perparkiran.

Bahwa terhadap Juru Parkir di tepi jalan umum mempunyai hak dan kewajiban yang harus dipenuhi oleh Juru Parkir di tepi jalan umum, yaitu haknya adalah mendapatkan pembinaan yang dilakukan oleh Dinas Perhubungan Kota Banda Aceh melalui Bidang Perparkiran yang mana pembinaan tersebut dilakukan dengan 2 (dua) cara yaitu dilakukan pembinaan secara peorangan dan pembinaan secara kolektif, sedangkan kewajibannya harus memenuhi sebagaimana tercantum

${ }^{1}$ Kurniawan Yoganing Dwijayanto, 'Pelaksanaan Peraturan Daerah Kabupaten Purbalingga Nomor 4 Tahun 2012 Tentang Penyelenggaraan Parkir Di Tepi Jalan Umum Dan Retribusi Pelayanan Parkir Di Tepi Jalan Umum Dalam Meningkatkan Pendapatan Asli Daerah' (2016) 5 Diponegoro Law Jurnal.[2]. 
pada Pasal 6 Peraturan Walikota Banda Aceh Nomor 6 Tahun 2013 tentang Penyelenggaraan Perparkiran.

\section{Metode Penelitian}

Metode penelitian yang bersifat yuridis empiris. Penelitian yuridis adalah menggunakan pendekatan peraturan perundang-undangan yaitu Qanun/Perda (dass sollen), sedangkan penelitian empiris menggunakan pendekatan lapangan (dass sein) dengan melakukan wawancara langsung terhadap Juru Parkir dan pengguna retribusi parkir.

\section{Pertanggungjawaban Juru Parkir Di Tepi Jalan Umum}

Menurut Hans Kelsen dalam teorinya tentang tanggung jawab hukum menyatakan bahwa: "seseorang bertanggung jawab secara hukum atas suatu perbuatan tertentu atau bahwa dia memikul tanggung jawab hukum, subyek berarti bahwa dia bertanggung jawab atas suatu sanksi dalam hal perbuatan yang bertentangan".2

Selanjutnya Hans Kelsen selanjutnya membagi mengenai tanggungjawab terdiri dari: ${ }^{3}$

“pertanggungjawaban individu yaitu seorang individu bertanggung jawab terhadap pelanggaran yang dilakukannya sendiri, pertanggungjawaban kolektif berarti bahwa seorang individu bertanggung jawab atas suatu pelanggaran yang dilakukan oleh orang lain, pertanggungjawaban berdasarkan kesalahan yang berarti bahwa seorang individu bertanggung jawab atas pelanggaran yang dilakukannya karena sengaja dan diperkirakan dengan tujuan menimbulkan kerugian, pertanggungjawaban mutlak yang berarti bahwa seorang individu bertanggung jawab atas pelanggaran yang dilakukannya karena tidak sengaja dan tidak diperkirakan".

Secara sederhana, "pertanggungjawaban hukum dapat dipahami sebagai suatu bentuk pertanggungjawaban oleh karena hukum menentukan demikian bahwa subjek hukum bertanggung jawab (Subjek hukum adalah pengembang hak

\footnotetext{
${ }^{2}$ Hans Kelsen, Teori Umum Hukum dan Negara, Dasar-Dasar Ilmu Hukum Normatif Sebagai Ilmu Hukum Deskriptif Empirik (BEE Media Indonesia 2007).[81].

${ }^{3}$ Hans Kelsen, Teori Hukum Murni Nuansa \& Nusa (Media 2006).[140].
} 
Hasfar Fuadi, dkk: Pertanggungjawaban Administratif Juru...

dan kewajiban. Subjek hukum terdiri dari manusia natuurlijke person dan badan hukum rechtspersoon. Akan tetapi, dalam kenyataannya tidak semua subjek hukum yang ditentukan oleh hukum untuk menanggung suatu pertanggungjawaban serta merta kepadanya dapat dimintai pertanggungjawaban, oleh karena beberapa unsur untuk menentukan suatu subjek hukum menanggung suatu pertanggungjawaban. ${ }^{4}$

Tugas pokok dari hukum adalah menciptakan ketertiban, oleh karena ketertiban merupakan syarat terpokok daripada adanya masyarakat yang teratur, hal mana berlaku bagi masyarakat manusia di dalam segala bentuknya. ${ }^{5}$ Dengan demikian pengertian-pengertian manusia, masyarakat dan hukum, merupakan pengertian-pengertian yang tidak dapat dipisah-pisahkan dari sosiologi hukum.

Dari uraian di atas terkait dengan pertanggungjawaban hukum, maka dapat disimpulkan pertanggungjawaban hukum terdiri dari tiga jenis, yaitu pertanggungjawaban hukum publik (hukum administrasi), pertanggungjawaban hukum perdata (privat) dan pertanggungjawaban hukum pidana. ${ }^{6}$ Adapun ketiga jenis pertanggungjawaban tersebut dapat diuraikan sebagai berikut:

a. Pertanggungjawaban hukum publik (hukum administrasi) atau menurut Philipus M. Hadjon tanggung gugat TUN pada dasarnya adalah tanggung gugat jabatan;

b. Tanggung jawab pidana adalah tanggung jawab pribadi, dalam kaitannya dengan tindak pemerintahan, tanggung jawab pribadi seorang pejabat berhubungan dengan adanya maladministrasi;

c. Tanggung jawab perdata dapat menjadi tanggung gugat jabatan berkaitan dengan perbuatan melanggar hukum oleh penguasa. Tanggung gugat perdata menjadi tanggung gugat pribadi apabila terdapat unsur maladministrasi.

\footnotetext{
${ }^{4}$ Mochtar Kusumaatmadja et.al, Pengantar Ilmu Hukum: Suatu Pengenalan Pertama Ruang Lingkup Berlakunya Ilmu Hukum (Alumni 2000).[80].

${ }^{5}$ Mokhammad Najih dan Soimin, Pengantar Hukum Indonesia: Sejarah, Konsep Tata Hukum, Dan Politik Hukum Indonesia (Intrans Publishing 2014).

${ }^{6}$ Philipus M. Hadjon, Hukum Administrasi dan Good Governance (Universitas Trisakti 2010).[96].
} 
Salah satu prinsip Negara hukum adalah asas legalitas, yang mengandung makna bahwa setiap tindakan hukum pemerintahan harus berdasarkan pada peraturan perundang- undangan yang berlaku atau setiap tindakan hukum pemerintahan harus berdasarkan pada kewenangan yang diberikan oleh peraturan perundang-undangan. Dengan bersandar pada asas legalitas itulah pemerintah melakukan berbagai tindakan hukum.

Karena pada setiap tindakan hukum itu mengandung makna penggunaan kewenangan, maka di dalamnya tersirat adanya kewajiban tanggungjawaban, sesuai dengan prinsip "geen bevoegdheid zonder verantwoordelijkheid". Berkaitan dengan hal tersebut, ada dua bentuk tanggungjawab, yaitu (1) tanggungjawab pribadi dan (2) tanggungjawab jabatan.

Tanggungjawab pribadi, berkaitan dengan pendekatan fungsionaris atau pendekatan perilaku. Dari sudut pandang hukum administrasi, tanggungjawab pribadi berkenaan dengan maladministrasi dalam penggunaan wewenang dalam pelayanan publik (public service). Penggunaan wewenang yang dimaksud disini meliputi tindakan pemerintahan menurut ketentuan peraturan perundangundangan dan tindakan dalam menetapkan suatu kebijakan atau diskresi.

Sedangkan tanggungjawab jabatan berkenaan dengan legalitas (keabsahan) tindak pemerintah. Dalam hukum administrasi persoalan legalitas tindak pemerintahan berkaitan dengan pendekatan terhadap kekuasaan pemerintah. Sehingga dalam pendekatan ini menentukan control atau pengawasan terhadap penggunaan kekuasaan. Dalam hal terdapat penyimpangan atau pelanggaran terhadap penggunaan kekuasaan oleh pemerintah, maka tanggungjawab Negara dilakukan atas dasar asas legalitas atau asas "rechtmatigheid".7

Bahwa dalam "memungut retribusi parkir di tepi jalan Umum, Dinas Perhubungan Kota Banda Aceh harus memperhatikan sebagaimana dimaksud dalam Qanun Kota Banda Aceh Nomor 4 Tahun 2012 tentang Retribusi Pelayanan

7 Tatiek Sri Djatmiati, Hukum Administrasi Dan Good Governance (Malaadministrasi Dalam Praktek Kesalahan Pribadi Dan Kesalahan Jabatan, Tanggungjawab Pribadi Dan Tanggungjawab Jabatan) (Universitas Trisakti 2016).[94]. 
Hasfar Fuadi, dkk: Pertanggungjawaban Administratif Juru...

Parkir di Tepi Jalan Umum" pada Pasal 7 ayat (1) disebutkan bahwa "prinsip dan sasaran dalam penetapan tarif retribusi ditetapkan dengan memperhatikan biaya penyediaan jasa yang bersangkutan, kemampuan masyarakat, aspek keadilan, dan efektivitas pengendalian atas pelayanan tersebut" ${ }^{8}$

Bahwa "dalam menjalankan tugasnya, seorang Juru Parkir juga memperoleh hak dan kewajibannya yaitu hak untuk mendapatkan pembinaan dan kewajibannya untuk menyetorkan hasil retribusinya kepada Pemerintah Kota Banda Aceh sebagai masukan pendapatan daerah sebagaimana tercantum dalam Peraturan Walikota Banda Aceh Nomor 6 Tahun 2013 tentang Penyelenggaran Perparkiran" dalam Pasal 12 ayat (2) menyebutkan bahwa "Besarnya bagi hasil untuk juru parkir di Tepi Jalan Umum adalah sebesar maksimal 65\% (enam puluh lima) persen dari potensi parkir".

Pada sisi yang lainnya, "pembagian retribusi parkir di tepi jalan umum yaitu 65\% (enam puluh lima) persen untuk juru parkir di tepi jalan umum dan 35 (tiga puluh lima) persen untuk Pemerintah Kota Banda Aceh. Pemungutan retribusi tersebut dilakukan sehari sekali oleh Petugas Juru Kutip dari Dinas Perhubungan Kota Banda Aceh dengan cara pembagiannya 65\% kepada Juru Parkir dan 35\% kepada Pemerintah Kota Banda Aceh, kemudian Petugas Juru Kutip menyerahkan bukti slip setoran kepada Juru Kutip".

Selanjutnya bahwa untuk Juru Pakir yang telah terdaftar atau resmi, mereka mendapatkan pembinaan yang diadakan oleh Dinas Perhubungan Kota Banda Aceh sebanyak 2 (dua) kali dalam setahun, pembinaan dilakukan dengan cara kumulatif dan perorangan. Dalam pembinaan tersebut dijelaskan hak dan kewajiban Juru Parkir dalam memungut retribusi parkir. Haknya adalah hak untuk memperoleh pembinaan serta kelengkapan atribut parkir berupa rompi, kartu identitas dan pluit.

Sedangkan "kewajibannya yaitu Juru Parkir wajibkan menyertorkan retribusinya kepada Juru Kutip sebagiamana dalam Qanun Nomor 4 Tahun 2012

\footnotetext{
${ }^{8}$ Qanun Kota Banda Aceh Nomor 4 Tahun 2012 tentang Retribusi Pelayanan Parkir di Tepi Jalan Umum (Lembaran Daerah Kota Banda Aceh Tahun 2012 Nomor 4 Seri C Nomor 1).
} 
tentang Retribusi Pelayanan Parkir di Tepi Jalan Umum pada Pasal 10 ayat (3)" dijelaskan bahwa "Retribusi dipungut dari Juru Parkir oleh Pengutip dengan menggunakan kupon sebagai tanda bukti pembayaran retribusi parkir".

Pada realisasinya terdapat ketidaksesuaian antara kebijakan yang telah ditetapkan dengan implementasi di lapangan. Beberapa masalah yang terjadi di lapangan yaitu terdapat juru parkir yang tidak dilengkapi dengan identitas yang legal seperti rompi yang dilengkapi nama dan nomor NIK dan kartu identitas.

Selain itu terdapat indikasi keterlibatan pihak ketiga (Oknum) yang tidak resmi melakukan pungutan dari Juru parkir. Aksi premanisme juga terjadi dalam proses pemungutan retribusi yang dilakukan oleh juru parkir. Dalam hal ini terdapat juru parkir illegal yang dengan sengaja menaiikan tarif retribusi parkir untuk keuntungannya.

Perilaku premanisme juru parkir tersebut mengakibatkan kerugian bagi masyarakat dan pemerintah Kota Banda Aceh. Karena keberadaannya yang ilegal, juru parkir liar tersebut tidak menyetorkan retribusi kepada Dinas Perhubungan Kota Banda Aceh sebagai PAD. Hal ini menyebabkan kebocoran PAD Kota Banda Aceh, pungutan yang seharusnya disetorkan ke kas daerah namun dimanfaatkan untuk kepentingan pribadi.

Minimnya kesadaran dan tingkat kedisiplinan masyarakat untuk tertib berlalulintas. Padatnya parkir pada jam-jam tertentu sehingga menyebabkan kemacetan di sejumlah ruas jalan pada jam tertentu, dan masih adanya tarif retribusi yang tidak sesuai ketentuan. Belum maksimalnya manajemen perparkiran yang dimiliki oleh UP parkiran, baik dari segi jumlah pegawai yang kurang untuk patrol pengawasan di lapangan, belum optimalnya koordinasi yang dijalankan untuk penanganan masalah parkir di lapangan, belum terealisasinya pencapaian target retribusi. ${ }^{9}$

Selain itu sebagian besar juru parkir tidak memberikan karcis sebagai bukti transaksi retribusi parkir sehingga penentuan besaran retribusi titik parkir

${ }^{9}$ Dicky Yusuf, 'Strategi Pengelolaan Dan Pemungutan Retribusi Parkir Di Kota Palu' (2019) 6 Jurnal Manajemen Transportasi \& Logistik.[44]. 
Hasfar Fuadi, dkk: Pertanggungjawaban Administratif Juru...

ditentukan dengan sistem kuota yang tidak didasari perhitungan yang jelas. Efek yang ditimbulkan dari masalah tersebut adalah terjadinya penyelewengan terhadap dana retribusi parkir dan mempengaruhi penerimaan daerah. ${ }^{10}$

Dari "uraian di atas terkait dengan pertanggungjawaban hukum, maka dapat disimpulkan pertanggungjawaban hukum terdiri dari tiga jenis, yaitu pertanggungjawaban hukum publik (hukum administrasi), pertanggungjawaban hukum perdata (privat), dan pertanggungjawaban hukum pidana. Ketiga jenis pertanggungjawaban hukum tersebut dapat diketahui" dalam uraian sebagai berikut:

"Pertanggungjawaban hukum publik adalah tanggung gugat jabatan. Tanggung jawab pidana adalah tanggung jawab pribadi, dalam kaitannya dengan tindak pemerintahan, tanggung jawab pribadi seorang pejabat berhubungan dengan adanya maladministrasi. Tanggung jawab perdata dapat menjadi tanggung gugat jabatan berkaitan dengan perbuatan melanggar hukum oleh penguasa. Tanggung gugat perdata menjadi tanggung gugat pribadi apabila terdapat unsur maladministrasi".

\section{Penerapan Sanksi Terhadap Juru Parkir}

Menurut "Kamus Besar Bahasa Indonesia, sanksi adalah tanggungan (tindakan atau hukuman) untuk memaksa orang menepati perjanjian atau menaati ketentuan undang-undang (anggaran dasar, perkumpulan, dan sebagainya)" berupa: "imbalan negatif, berupa pembebanan atau penderitaan yg ditentukan dalam hukum, imbalan positif, yg berupa hadiah atau anugerah yg ditentukan dalam hukum". ${ }^{11}$

Sanksi menurut hukum administrasi adalah "alat kekekuasaan yang bersifat hukum publik yang dapat digunakan oleh pemerintah sebagai reaksi atas ketidakpatuhan terhadap kewajiban yang terdapat dalam norma Hukum Administrasi Negara." "Berdasarkan definisi ini tampak ada empat unsur sanksi dalam hukum administrasi Negara, yaitu alat kekuasaan (machtmiddelen), bersifat

${ }^{10}$ Dewi Fitri Liana, 'Implementasi Kebijakan Pemerintah Kota Banda Aceh Terhadap Retribusi Parkir (Suatu Kajian Dalam Peningkatan PAD Kota Banda Aceh Tahun 2012-2013)’ (2018) 3 Jurnal Ilmiah Mahasiswa FISIP Unsyiah.[4].

${ }^{11}$ Balai Pustaka, Kamus Besar Bahasa Indonesia (Depdikbud 1995).[1265]. 
hukum publik (publiekrechtlijke), digunakan oleh pemerintah (overheid), sebagai reaksi atas ketidakpatuhan (reactive op niet-naleving)". ${ }^{12}$

Pada "umumnya macam-macam dan jenis sanksi itu dicantumkan dan ditentukan secara tegas dalam peraturan perundang-undangan bidang administrasi tertentu. Secara umum dikenal beberapa macam sanksi dalam hukum administrasi" yaitu: ${ }^{13}$

"Paksaan pemerintah (bestuursdwang) yaitu sebagai kewenangan organ pemerintahan untuk melakukan tindakan nyata mengakhiri situasi yang bertentangan dengan norma hukum administrasi negara karena kewajiban yang muncul dari norma itu tidak dijalankan atau sebagai reaksi dari pemerintah atas pelanggaran norma hukum yang dilakukan warga negara. Penarikan kembali keputusan yang menguntungkan (Izin, subsidi, pembayaran dan sebagainya) yaitu keputusan itu memberikan hak-hak atau memberikan kemungkinan untuk memperoleh sesuatu melalui keputusan atau bilamana keputusan itu memberikan keringanan beban yang ada atau mungkin ada. Pengenaan uang paksa oleh pemerintah (dwangsom) yaitu alternatif untuk tindakan nyata, yang berarti sebagai sanksi (subsidiaire) dan dianggap sebagai reparatoir. Jika terjadi pelanggaran atau pelanggar (pemegang izin) tidak segera mengakhirinya, maka uang jaminan dipotong sebagai dwangsom. Uang jaminan ini lebih banyak digunakan ketika pelaksanaan bestuurdwang sulit dilakukan. Pengenaan denda administratif (admnistratieve boete) yaitu pengenaan denda administratif tanpa perantaraan hakim ini tidak berarti pemerintah dapat menerapkannya secara sewenangwenang (arbitrer)".

Hal tersebut berarti merupakan dampak dari pada pertanggungjawaban Juru Parkir apabila di lokasi parkir terjadi hal-hal yang tidak diinginkan. Misalnya kehilangan motor, kehilangan helm, terjadi kerusakan pada kendaraan yang diparkir, dan lain-lain. Jika seorang Juru Parkir tidak mau bertanggung jawab atas kehilangan motor, kehilangan helm, atau kerusakan pada kendaraan yang diparkir, maka hal ini akan menimbulkan konflik baru antara Pengendara sepeda motor dengan Juru Parkir Liar tersebut. Seorang Juru Parkir Liar tidak mau bertanggung jawab atas hilangnya helm milik pengendara motor yang parkir dilokasi tersebut.

\footnotetext{
${ }^{12}$ Ridwan HR, Hukum Administrasi Negara (Rajagrafindo Persada 2016).[315].

${ }^{13}$ ibid. [303].
} 
Hasfar Fuadi, dkk: Pertanggungjawaban Administratif Juru...

Selain itu dengan tidak membawa Surat Penunjukan atau Kartu Tanda Anggota Juru Parkir serta tidak memakai atribut resmi seperti rompi dan karcis dapat membuat kepercayaan masyarakat kepada Juru Pakir tersebut berkurang sehingga dapat menimbulkan keresahan kepada masyarakat. Padahal satu-satunya yang dapat membuktikan bahwa resmi atau tidaknya seorang Juru Pakir hanya bisa di lihat melalui Surat Penunjukan dan Kartu Tanda Anggota Juru Parkir.

Dengan adanya Juru Parkir yang melanggar tetapi tidak diberikan sanksi yang tegas tentunya akan membuat Juru Parkir lainya berpotensi untuk melakukan pelanggaran juga. Dengan kata lain Juru Parkir Liar akan semakin banyak ditemui. Selain itu semakin banyak Juru Parkir Liar tentunya akan semakin cepat meluasnya budaya akan korupsi di kalangan Juru Parkir. ${ }^{14}$

Perihal ini sangat bergantung pada pengawasan terhadap Juru Parkir di tepi jalan umum dengan memeriksa dan mengawasi juru parkir yang bertugas di lapangan apakah sudah melaksanakan tugas dan kewajibannya dengan benar seperti memberikan karcis parkir kepada pengguna jasa parkir tepi jalan umum, memungut tarif retribusi sesuai dengan aturan yang berlaku dan tertera pada karcis parkir, dan sebagainya. ${ }^{15}$

Berdasarkan "Qanun Kota Banda Aceh Nomor 4 Tahun 2012 tentang Retribusi Pelayanan Parkir Di Tepi Jalan Umum, terkait dengan sanksi telah diatur dengan dibagi atas 2 (dua) macam sanksi yaitu sanksi Administrasi dan saksi Pidana sebagaimana pada Pasal 18 dan 19 ayat (1)."

Pada Pasal 18 disebutkan bahwa “Dalam hal Wajib Retribusi tidak membayar tepat pada waktunya atau kurang bayar, dikenakan sanksi administrasi berupa bunga sebesar $2 \%$ (dua persen) setiap bulan dari Retribusi yang terutang yang tidak atau kurang dibayar dan ditagih dengan menggunakan STRD". Sedangkan

${ }^{14}$ Bimo Aldhy Syahfiputro, 'Efektivitas Pasal 15 Peraturan Daerah Kota Malang Nomor 4 Tahun 2009 Tentang Pengelolaan Tempat Parkir Yang Berkaitan Dengan Kartu Tanda Pengenal Juru Parkir' (Universitas Muhammadiyah Malang, 2018) <http://eprints.umm.ac.id/id/eprint/37848 22>, dikunjungi pada 22 Juli 2021.

15 Tri Maryugo Hawati, 'Strategi Optimalisasi Penerimaan Retribusi Pelayanan Parkir Tepi Jalan Umum Kota Tangerang Selatan' (2017) 19 Jurnal Penelitian Transportasi Darat.[66]. 
pada Pasal 19 ayat (1) disebutkan bahwa "wajib Retribusi yang tidak melaksanakan kewajibannya sehingga merugikan keuangan daerah diancam pidana kurungan paling lama 3 (tiga) bulan atau pidana denda paling banyak 3 (tiga) kali jumlah Retribusi terutang yang tidak atau kurang dibayar".

Dalam "pelakasanaannya masih juga didapati oleh Dinas Perhubungan Kota Banda Aceh adanya Juru Parkir yang terdaftar melakukan tindakan melawan hukum seperti halnya tertulis dalam surat perjanjian, maka Dinas Perhubungan Kota Banda Aceh memberikan toleransi terhadap Juru Parkir yang tidak bertanggungjawab dengan tidak langsung memberikan sanksi melainkan memberikan peringatan, namum apabila Juru Parkir masih melakukan hal yang sama maka Dinas Perhubungan Kota Banda Aceh dapat memberikan sanksi berupa pembatalan Surat Perjanjian tersebut. ${ }^{16 \prime}$

Dengan tujuan dilakukannya penerapan sanksi tersebut sebagaimana diutarakan dalam Asas Umum Pemerintahan yang baik ini lebih mengikat secara moral karena asas-asas tersebut belum pernah dituangkan secara resmi dalam peraturan perundang-undangan sebagai asas-asas umum pemerintahan, sehingga kekuatan hukumnya secara yuridis formal belum ada sebagaimana diuraikan oleh Koentjoro Purbopranoto: ${ }^{17}$

"Azas kepastian hukum (Principle of Legal Security); Azas keseimbangan (Principle of Proportionality); Azas kesamaan dalam mengambil keputusan (Principle of Equality); Azas bertindak cermat (Principle of Carefulness); Azas motivasi untuk setiap keputusan (Principle of Motivation); Azas jangan mencampur-adukkan kewenangan (Principle of Non Misuse of Competence); Azas permainan yang layak (Principle of Fair Play); Azas keadilan atau kewajaran (Principle of Reasonable or Prohibition of Arbitrariness); Azas menanggapi pengharapan yang wajar (Principle of Meeting Raised Expectation); Azas meniadakan akibat suatu keputusan yang batal (Principle of Undoing The Consequences of An Annulled Decision); Azas perlindungan atas pandangan (cara) hidup pribadi (Principle of Protecting The Personal Way of Life); Azas kebijaksanaan (Sapientia); Azas penyelenggaraan kepentingan umum (Principle of Public Service)".

${ }^{16}$ Muazzinah, 'Analisis Tata Kelola Retribusi Parkir Sebagai Upaya Peningkatan Pendapatan Asli Daerah Kota Banda Aceh’ (2020) 5 Al-Ijtima' i.[129].

${ }^{17}$ SF. Marbun dan Moh. Mahfud MD, Pokok-Pokok Hukum Administrasi Negara (Edisi Revisi) (Liberty 2016).[58]. 
Hasfar Fuadi, dkk: Pertanggungjawaban Administratif Juru...

\section{Kesimpulan}

Pertanggungjawaban secara administratif terhadap Juru Parkir dalam melaksanakan kewajibannya wajib menggunakan pakaian/rompi resmi yang diberikan oleh Dinas Perhubungan Kota Banda Aceh, Juru Parkir pada saat memungut retribusi parkir wajib menyerahkan kupon kepada pengguna jasa retribusi sebagai bukti pungutan retribusi parkir dan Juru Parkir wajib menyerahkan hasil retribusi kepada Pemerintah Kota Banda Aceh melalui Juru Kutip yang ditugaskan sesuai dengan ketentuan yang telah ditetapkan, namum apabila Juru Parkir tidak dalam pelaksanaan kewajibannya tidak bertanggung jawab maka dapat diberikan sanksi berupa pembatalan Surat Perjanjian Tata Kelola Pemungutan Retribusi Parkir.

\section{Daftar Bacaan}

\section{Buku}

Balai Pustaka, Kamus Besar Bahasa Indonesia (Depdikbud, 1995).

Hans Kelsen, Teori Hukum Murni Nuansa E Nusa (Media 2006).

., Teori Umum Hukum dan Negara, Dasar-Dasar Ilmu Hukum Normatif Sebagai Ilmu Hukum Deskriptif Empirik (BEE Media Indonesia 2007).

Mochtar Kusumaatmadja et.al, Pengantar Ilmu Hukum:Suatu Pengenalan Pertama Ruang Lingkup Berlakunya Ilmu Hukum (Alumni 2000).

Mokhammad Najih dan Soimin, Pengantar Hukum Indonesia: Sejarah, Konsep Tata Hukum, Dan Politik Hukum Indonesia (Setara Press 2014).

Philipus M. Hadjon, Hukum Administrasi dan Good Governance (Universitas Trisakti 2010).

Ridwan HR, Hukum Administrasi Negara (Rajagrafindo Persada 2016).

SF. Marbun dan Moh. Mahfud MD, Pokok-Pokok Hukum Administrasi Negara (Edisi Revisi) (Liberty 2016).

Tatiek Sri Djatmiati, Hukum Administrasi Dan Good Governance (Malaadministrasi Dalam Praktek Kesalahan Pribadi Dan Kesalahan Jabatan, Tanggungjawab Pribadi Dan Tanggungjawab Jabatan) (Universitas Trisakti 2016). 


\section{Jurnal}

Dewi Fitri Liana, 'Implementasi Kebijakan Pemerintah Kota Banda Aceh Terhadap Retribusi Parkir (Suatu Kajian Dalam Peningkatan PAD Kota Banda Aceh Tahun 2012-2013)' (2018), 3 Jurnal Ilmiah Mahasiswa FISIP Unsyiah.

Dicky Yusuf, 'Strategi Pengelolaan Dan Pemungutan Retribusi Parkir Di Kota Palu' (2019) 6 Jurnal Manajemen Transportasi \& Logistik.

Kurniawan Yoganing Dwijayanto, 'Pelaksanaan Peraturan Daerah Kabupaten Purbalingga Nomor 4 Tahun 2012 Tentang Penyelenggaraan Parkir Di Tepi Jalan Umum Dan Retribusi Pelayanan Parkir Di Tepi Jalan Umum Dalam Meningkatkan Pendapatan Asli Daerah' (2016) 5 Diponegoro Law Jurnal.

Muazzinah, 'Analisis Tata Kelola Retribusi Parkir Sebagai Upaya Peningkatan Pendapatan Asli Daerah Kota Banda Aceh' (2020) 5 Al-Ijtima'I.

Tri Maryugo Hawati, 'Strategi Optimalisasi Penerimaan Retribusi Pelayanan Parkir Tepi Jalan Umum Kota Tangerang Selatan' (2017) 19 Jurnal Penelitian Transportasi Darat.

\section{Karya Ilmiah}

Bimo Aldhy Syahfiputro, 'Efektivitas Pasal 15 Peraturan Daerah Kota Malang Nomor 4 Tahun 2009 Tentang Pengelolaan Tempat Parkir Yang Berkaitan Dengan Kartu Tanda Pengenal Juru Parkir' (Universitas Muhammadiyah Malang, 2018) <http:/ / eprints.umm.ac.id/id/eprint/3784822>, dikunjungi pada 22 Juli 2021.

\section{Perundang-undangan}

Qanun Kota Banda Aceh Nomor 4 Tahun 2012 tentang Retribusi Pelayanan Parkir di Tepi Jalan Umum (Lembaran Daerah Kota Banda Aceh Tahun 2012 Nomor 4 Seri C Nomor 1$)$.

Peraturan Walikota Banda Aceh Nomor 6 Tahun 2013 tentang Penyelenggaraan Perparkiran (Berita Daerah Kota Banda Aceh Tahun 2013 Nomor 6).

How to cite: Hasfar Fuadi, Ilyas Ismail dan M. Saleh, ‘Pertanggungjawaban Administratif Juru Parkir di Tepi Jalan Umum Dalam Pemungutan Retribusi' (2021) Vol. 4 No. 3 Media Iuris. 
--Halaman ini sengaja dibiarkan kosong-- 